STUDIES IN PHILOSOPHY 



\title{
CAJETAN'S NOTION OF EXISTENCE
}

by

\author{
JOHN P. REILLY
}

Salve Regina College, Newport, R.I.

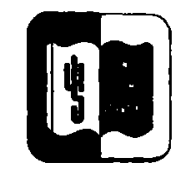

1971

MOUTON

THE HAGUE - PARIS 
(c) Copyright 1971 in The Netherlands.

Mouton \& Co. N.V., Publishers, The Hague.

No part of this book may be translated or reproduced in any form, by print, photoprint, microfilm, or any other means, without written permission from the publishers.

LIBRARY OF CONGRESS CATALOG CARD NUMBER: 71-85900

Printed in The Netherlands by Mouton \& Co., Printers, The Hague. 